\title{
Assessment of FTA card employment for Pasteurella multocida DNA transport and detection of virulence-associated genes in strains isolated from fowl cholera in the United States
}

\author{
[Avaliação do emprego de cartões FTA para o transporte do DNA de Pasteurella multocida e pesquisa \\ de genes associados à virulência em cepas isoladas de cólera aviária nos Estados Unidos] \\ C.N. Almeida ${ }^{1}$, T.Q. Furian ${ }^{1 *}$, K.A. Borges ${ }^{1}$, G. Perdoncini ${ }^{1}$, M.J. Mauel ${ }^{2}$, S.L.S. Rocha ${ }^{1}$, \\ V.P. Nascimento ${ }^{1}$, C.T.P. Salle ${ }^{1}$, H.L.S. Moraes $^{1}$ \\ ${ }^{1}$ Centro de Diagnóstico e Pesquisa em Patologia Aviária - Faculdade de Veterinária - Universidade Federal do Rio \\ Grande do Sul - Porto Alegre, RS \\ ${ }^{2}$ College of Veterinary Medicine - Mississippi University - Stoneville - MS, EUA
}

\begin{abstract}
Fowl Cholera (FC) is a disease caused by Pasteurella multocida. The severity of this disease is partly caused by virulence factors. Genes encoding fimbriae, capsule, sialidases and proteins for iron metabolism may be related to P. multocida's ability to infect the host. Besides to examining DNA for the presence of virulence genes, DNA is essential for the diagnostic and FTA cards are an alternative for genetic material transport. The study aims to evaluate the viability of $P$. multocida DNA transport using the cards and to detect 14 virulence genes in 27 strains isolated from FC cases in the United States by multiplex-PCR. No growth was observed in any of the FTA cards, which was essential to assess the security. Furthermore, DNA detection was possible in $100 \%$ of the samples, independent of the storage period ( 7 to 35 days) and temperature $\left(4^{\circ} \mathrm{C}\right.$ and $\left.37^{\circ} \mathrm{C}\right)$. ptfA, exbd-tonB, hgbA, nanB, oma 87 , hyaD-hyaC, sodC, $h g b B$, sodA, nanH and $p f h A$ genes were detected in more than $80 \%$ of the samples. FTA cards have proven to be a viable and safe tool for DNA transport of $P$. multocida. A majority of genes showed a high frequency, which was similar to strains isolated from FC cases.
\end{abstract}

Keywords: fowl cholera, FTA cards, virulence genes

\section{RESUMO}

Cólera aviária (CA) é uma doença causada pela bactéria Pasteurella multocida e a severidade dos casos é em parte justificada por fatores de virulência. Genes codificando fímbrias, cápsulas, sialidases, dismutases e proteínas do metabolismo férrico podem ser relacionados à capacidade do agente em infectar o hospedeiro. Além da obtenção do DNA para pesquisa de genes de virulência, o material genético é fundamental para o diagnóstico, e os cartões FTA seriam uma alternativa no transporte de microrganismos. Os objetivos da presente pesquisa foram avaliar a viabilidade do transporte de DNA de P. multocida através dos cartões e detectar 14 genes de virulência em 27 cepas isoladas de CA nos Estados Unidos, por meio de multiplex-PCR. Nenhuma das amostras para análise microbiológica da segurança dos cartões apresentou crescimento. Foi possível a detecção do DNA em 100\% das amostras, independentemente do tempo de estocagem (sete a 35 dias) e das temperaturas $\left(4^{\circ} \mathrm{C}\right.$ e $37^{\circ} \mathrm{C}$ ) avaliadas. Genes ptfA, exbd-tonB, hgbA, nanB, oma87, hyaD-hyaC, sodC, hgbB, sodA, nanH e pfhA foram detectados em mais de $80 \%$ das amostras. Os cartões FTA demonstraram ser uma ferramenta viável e segura para o transporte do DNA de P. multocida. A maioria dos genes apresentou uma alta frequência, compatível com isolados de CA.

Palavras-chave: cólera aviária, cartões FTA, genes de virulência

Recebido em 16 de fevereiro de 2017

Aceito em 22 de maio de 2018

*Autor para correspondência (corresponding author)

E-mail: thales.furian@ufrgs.br 


\section{INTRODUCTION}

Pasteurella multocida is the etiological agent of Fowl Cholera (FC), a contagious disease that causes septicemia and results in high rates of morbidity and mortality (Wilkie et al., 2012). Furthermore, $P$. multocida is a common inhabitant of the respiratory tract of animals, and the imbalance of the relationship between the host and bacteria can cause different disease manifestations (Glisson et al., 2008). The severity of cases is partly caused by the presence of virulence factors, and the main virulence factors identified in P. multocida are the capsule and lipopolysaccharide (Harper et al., 2006). Considering these structures, these bacteria can also be classified into five serogroups (A, B, D, $\mathrm{E}$ and $\mathrm{F}$ ) according to the presence of capsular antigens and into 16 serotypes according to the distribution of the somatic antigens (Harper et al., 2006).

This classification is used to investigate the diversity of strains (Christensen and Bisgaard, 2006) because it suggests a possible interrelationship between the capsule, pathogenesis, and host predisposition to a particular serogroup (Chung et al., 1998). However, many other factors may be related to the agent's ability to infect the host, including the ability to survive in a hostile environment (Wilkie et al., 2012). In recent years, genome sequencing of some $P$. multocida strains has led to the identification of genes that may be associated with virulence, thereby representing a first step toward the elucidation of the molecular mechanisms involved in the pathogenesis of this bacterium (Boyce et al., 2012).

After the genome analysis of the strain PM70, more than 100 genes likely involved in the virulence of the microorganism were identified (May et al., 2001; Boyce et al., 2012). In recent years, some studies determined the frequency and genetic virulence patterns and contributed to the elucidation of the pathogenesis of $\mathrm{CA}$; for example, some studies associated specific genes to the development of acute or chronic disease forms (Ewers et al., 2006; Tang et al., 2009). Examples are genes encoding structures, such as fimbriae and adhesins ( $p t f A, p f h A)$, dismutases $(\operatorname{sod} A, \operatorname{sod} C)$, proteins associated with iron

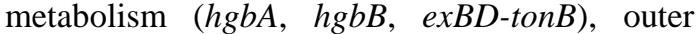
membrane proteins (oma87) and the exotoxin dermonecrotic (toxA) (Ewers et al., 2006; Hatfaludi et al., 2010). Most genes that are transcribed during the infection are also involved in nutrient acquisition and metabolic processes (Boyce and Adler, 2006). Highly virulent strains of $P$. multocida often secrete several hydrolytic enzymes, such as sialidases (nanH, nanB), that facilitate nutrient acquisition and dissemination in the body (Wilson and Ho, 2013).

In addition to detecting virulence associated genes, DNA is essential for the diagnosis and molecular discrimination of $P$. multocida, especially considering the difficulty of agent isolation in clinical cases and limited survival of the microorganism outside the host or in culture media (Christensen and Bisgaard, 2006). Similarly, acute FC should be differentiated from notifiable diseases, such as avian influenza and Newcastle disease (Glisson, 2008), which increases the need for rapid diagnosis and safe transport of material to the laboratory (Perozo et al., 2006).

The transport of biological material is regulated by international and national standards, which are often complex (Brasil, 2009; Guidance..., 2009). FTA cards (Flinders Technology Associates Filter Paper - WHATMAN ${ }^{\circledR}$ ), which are chemically treated with substances that lyse the cells and denature the proteins, are safe alternatives for the transport of inactivated microorganisms (Perozo et al., 2006; Cortes et al., 2009). This technology simplifies sample storage, transport and extraction, thereby reducing the cost and time required for diagnosis (Mbogori et al., 2006). FTA cards have been employed in studies for transport and subsequent detection of poultry pathogens by PCR or RTPCR (Moscoso et al., 2004; Perozo et al., 2006; Cortes et al., 2009; Pulido-Landínez et al., 2012; Awad et al., 2014).

In this context, the objectives of this study were to evaluate the viability of $P$. multocida DNA transport using FTA cards and to detect 14 genes associated with virulence in strains isolated from fowl cholera cases in the United States, comparing the occurrence to Brazilian strains results. 


\section{MATERIALS AND METHODS}

A total of 27 samples of $P$. multocida isolated from clinical cases of FC in broiler breeders (15 to 61 weeks old) during 2012 and 2013 at the Poultry Research and Diagnostic Laboratory of Mississippi State University in the United States were selected for this study. The samples were stored at a temperature of $-80^{\circ} \mathrm{C}$, and reactivation was performed as described by Glisson et al. (2008) and Furian et al. (2016) at the laboratory previously cited. The strains were inoculated in $10 \mathrm{~mL}$ of brain heart infusion broth (Thermo Fischer Scientific - Remel ${ }^{\mathrm{TM}}$; Lenexa, USA) and incubated at $37^{\circ} \mathrm{C}$ for 24 hours. Then, the samples were plated on blood agar (Thermo Fischer Scientific - Remel ${ }^{\mathrm{TM}}$; Lenexa, USA) supplemented with 5\% defibrinated sheep blood and on MacConkey agar (Thermo Fischer Scientific - Remel ${ }^{\mathrm{TM}}$; Lenexa, USA). MacConkey agar was used for discrimination of other members of the Pasteurellaceae family that can grow on this agar (Glisson et al., 2008). The plates were incubated at $37^{\circ} \mathrm{C}$ for 24 hours, and one colony on blood agar was selected for the catalase and oxidase tests and the Giemsa staining to observe the characteristics of bipolar cells.

A morphologically compatible colony of each sample was transferred to $10 \mathrm{~mL}$ of BHI broth, and the material was incubated again according to the described conditions. After incubation overnight, $115 \mu \mathrm{L}$ of $\mathrm{BHI}$ were pipetted onto FTA cards (Whatman ${ }^{\mathrm{TM}}$ - GE Healthcare ${ }^{\circledR}$ - Cat. No. WB12 0206; Little Chalfont, United Kingdom), and the samples were kept in a biological safety cabinet until complete drying and absorption of the solution onto the filter paper (Pulido-Landínez et al., 2012).

The DNA extraction was performed in a biological safety cabinet. The extraction from FTA cards was performed according to the protocol established by Pulido-Landínez et al. (2012). Discs 3mm in diameter were collected from the cards, using the sample collector FTA Harris Uni-Core (Whatman $^{\mathrm{TM}}-G E$ Healthcare $^{\circledR}$; Little Chalfont, United Kingdom) and the mat Harris as a base for cutting (Harris CuttingMat - GE Healthcare ${ }^{\circledR}$; Little Chalfont, United Kingdom). To obtain the discs, the collector was positioned vertically, and the steel cutting edge of the Uni-core collector was pressed firmly against the area for collection, while circular movements were made for card cutting. The discs were transferred to sterile $1.5 \mathrm{~mL}$ Eppendorf tubes before adding $200 \mu \mathrm{L}$ of FTA Purification Reagent (WhatmanTM - GE Healthcare $^{\circledR}$; Little Chalfont, United Kingdom) (Pulido-Landínez et al. 2012; Pulido-Landínez et al., 2013). Later, three washes, separated by a 5 minute incubation period at $25^{\circ} \mathrm{C}$, were performed with FTA Purification Reagent. Then, after discarding the purification reagent, $200 \mu \mathrm{L}$ of TE buffer were added (10mM Tris-HCl, $0.1 \mathrm{mM}$ EDTA, $\mathrm{pH} 8.0$ ), and two washes were performed again as described above. The extracted DNA was stored for further quantification and the detection of virulenceassociated genes (Pulido-Landínez et al. 2012; Pulido-Landínez et al., 2013).

After extracting DNA, DNA quantification and a PCR was performed for feasibility assessment. Before PCR, DNA was quantified using a commercial kit, Quant-iTdsDNA HS Assay (Invitrogen ${ }^{\circledR}$; Carlsbad, USA), according to the manufacturer's instructions. DNA quantifications were performed using a Qubit fluorometer (Invitrogen $^{\circledR}$; Carlsbad, USA). The speciesspecific protocol (Townsend et al., 1998) was used to amplify part of the kmt gene, which was 460bp in length.

To evaluate the microbiological safety of the FTA cards, a disk of $3 \mathrm{~mm}$ in diameter and corresponding to each sample was collected and transferred to a tube containing $10 \mathrm{~mL}$ of $\mathrm{BHI}$ broth (Pulido-Landínez et al. 2012; PulidoLandínez et al., 2013). After incubation at $37^{\circ} \mathrm{C}$ for 24 hours, the turbidity of BHI, which indicates the growth in the broth medium, was evaluated (Pulido-Landínez et al., 2012; PulidoLandínez et al., 2013). In the case of turbidity of the BHI, the broth would be plated on blood agar (Oxoid $^{\circledR}$; Cambridge, United Kingdom) supplemented with 5\% defibrinated sheep blood and on MacConkey agar (Oxoid ${ }^{\circledR}$; Cambridge, United Kingdom) and incubated at $37^{\circ} \mathrm{C}$ for 24 hours (approximately $10^{8} \mathrm{CFU} / / \mathrm{mL}$ ). In the case of growth, colony morphologies on blood agar would be evaluated. The same steps described for the samples reactivation and other biochemical tests using the Bactray III system (Laborclin $^{\circledR}$, Pinhais, Brazil) would be performed. 
Same-sized discs stored at $4{ }^{\circ} \mathrm{C}$ and $37^{\circ} \mathrm{C}$ and that contained the 27 samples were collected at 7,14 , 21, 28 and 35 days after inoculation to evaluate stability of FTA cards. DNA was extracted as described previously, and the PCR protocol for amplification of the kmt gene was performed (Townsend et al., 1998).

Previously standardized multiplex PCR protocols were employed (Furian et al., 2016) to detect the 14 virulence-associated genes (toxA, ptfA, pfhA, nanH, nanB, exbd-tonB, hgbA, hgbB, sodA, sodC, hyaD-hyaC, dcbF, bcbD, oma87). The reference strains of $P$. multocida (ATCC 12945) and Bordetella avium (ATCC 35086) were selected as positive and negative controls, respectively. Amplification was performed in a thermocycler (Swift MaxPro Thermal CyclerESCO Technologies ${ }^{\circledR}$; Singapore), according to the conditions described by Furian et al. (2016). Electrophoresis of amplified products was carried out in an agarose gel (Invitrogen ${ }^{\circledR}$; Carlsbad, USA) at $1 \%$ and $1.5 \%$ that was stained with ethidium bromide, and the gels were photodocumented (AlphaDigidoc ${ }^{\circledR}$ Pro system Alpha Innotech; San Leandro, United States) for the interpretation of the results.

Descriptive statistical analysis was used to calculate the absolute and relative frequency of virulence genes and to determine the mean and standard deviation of the DNA concentration. The nonparametric Chi-Square $\left(\chi^{2}\right)$ and Fisher's exact test were used to compare the frequency of virulence genes among different regions of isolation. The McNemar test was used to determine and to compare the frequency of virulence genes within the same function group. The PASW Statistics ${ }^{\circledR}$ was used, adopting the significance level of $5 \%$ and the confidence level of $95 \%$.

\section{RESULTS AND DISCUSSION}

None of the strains presented turbidity of BHI. Thus, the plating on blood agar and on MacConkey agar was not performed. The safety of the FTA cards had already been reported in studies that also evaluated the inactivation of viruses and avian pathogenic bacteria by the transport cards (Perozo et al., 2006; PulidoLandínez et al., 2012).
Regarding the viability of FTA cards, $100 \%$ $(27 / 27)$ of the strains in the study were confirmed by amplification of a $460 \mathrm{bp}$ fragment of the $\mathrm{kmt}$ gene through PCR. Similarly, the mean concentration of DNA was $54.54 \mathrm{ng} / \mu \mathrm{L} \pm 30.03$, with a minimum observed value of $13.40 \mathrm{ng} / \mu \mathrm{L}$ and a maximum of $100 \mathrm{ng} / \mu \mathrm{L}$. Similar concentrations have been described by PulidoLandínez et al. (2012) using FTA cards for the transporting of Salmonella DNA samples isolated from poultry products. In addition, the DNA was feasible for the detection of virulenceassociated genes using multiplex PCR protocols standardized with strains isolated from clinical cases in Brazil (Furian et al., 2016). As observed by studies of viral and bacterial pathogens in poultry health areas, the FTA cards have proven to be an alternative for safe transport of DNA samples of P. multocida (Moscoso et al., 2004; Perozo et al., 2006; Cortes et al., 2009; PulidoLandínez et al., 2012; Awad et al., 2014).

The accuracy and sensitivity of molecular diagnosis may be affected by the presence of enzymes that induce the degradation of nucleic acids, which occurs in the interval between the collection and processing of samples. This issue is aggravating for veterinary diagnosis because poultry farms are not located near laboratories (Liang et al., 2014). Inside the FTA cards, nucleic acids were retained in the membrane and protected from oxidation damage by UV rays, indicating they can be stored at room temperature (Perozo et al., 2006; Cortes et al., 2009). It was confirmed in the present study, since it was possible to detect $P$. multocida DNA, regardless of storage time - 7 to 35 days and temperature $-4^{\circ} \mathrm{C}$ and $37^{\circ} \mathrm{C}$. A similar finding was reported by Moscoso et al. (2004), where they evaluated the stability of DNA of Mycoplasma synoviae and M. gallisepticum in FTA cards after 60 days of storage.

The occurrence of virulence genes in the 27 strains from the United States was similar to the 56 isolates from Southern Brazil in our previous study (Furian et al., 2016), showing no significant difference ( $\mathrm{P}>0.05)$. However, the restricted number of isolates used for this comparison suggests further studies to confirm the results. The absolute and relative frequencies of 14 virulence-associated genes studied are described in Table 1. 
Table 1. Distribution of 14 virulence associated genes of Pasteurella multocida in strains isolated from breeders with fowl cholera in the United States detected by multiplex-PCR

\begin{tabular}{ccc}
\hline Process or enzyme & Gene & $\begin{array}{c}\text { Absolute and relative frequencies }(\%)- \\
(\mathrm{n}=27)\end{array}$ \\
\hline Outer membrane protein & oma87 & $27(100)$ \\
exbD-tonB & hgbA & $27(100)$ \\
Iron metabolism & hgbB & $27(100)$ \\
Sialidases & nanH & $26(96.3)$ \\
& nanB & $23(85.2)$ \\
Superoxide dismutases & sodA & $27(100)$ \\
Toxin dermonecrotic & sodC & $25(92.6)$ \\
Adhesins & toxA & $26(96.3)$ \\
& ptfA & $0(0)$ \\
Capsular type & pfhA & $27(100)$ \\
& hyaD-hyaC & $22(81.5)$ \\
& $d c b F$ & $27(100)$ \\
& $b c b D$ & $0(0)$ \\
\hline
\end{tabular}

The mild variations in the gene distribution patterns are probably associated with the acquisition of virulence genes through evolution and horizontal transmission within the $P$. multocida population (Tang et al., 2009). Thus, discrimination of $P$. multocida avian strains isolated from different geographical regions based on the distribution of genes studied is not appropriate, and the use of traditional molecular techniques, such as PCR-RFLP (Restriction Fragment Length Polymorphism) and MLST (Multilocus Sequence Typing) is instead suggested (Subaaharan et al., 2010; Tsai et al., 2011).

Most virulence genes studied showed a high frequency and regular distribution. Thus, there was no significant difference in the occurrence of genes in the same function or associated process (P> 0.05). The exception was for the hyaD-hyaC gene, which is specific to serogroup A and was seen in $100 \%(27 / 27)$ of strains; this is in comparison to the occurrence of the $d c b F$ and $b c b D$ genes, which correspond to serogroups $\mathrm{B}$ and $\mathrm{D}$, respectively, and were not detected in the present study $(\mathrm{P}<0.05)$.

Classification into serogroups is used to investigate strain diversity and study of bacterial pathogenesis and epidemiology (Christensen and Bisgaard, 2006). Despite the relationship to certain diseases and species, these associations have varied in some hosts (Katoch et al., 2015). The capsular type A is predominant in FC cases, while serogroup $\mathrm{B}$ and $\mathrm{F}$ are uncommon in birds (Glisson, 2008).

The majority of genes that are transcribed during an infection are also involved in nutrient acquisition and metabolic processes (Boyce and Adler, 2006). Highly virulent strains of $P$. multocida often secrete hydrolytic enzymes, such as sialidases, that facilitate nutrient acquisition and dissemination in the organism (Wilson and Ho, 2013). As an example, $\mathrm{NanH}$ and $\mathrm{NanB}$ remove sialic acid from the host cells as a carbon source (Harper et al., 2006). The genes encoding the two enzymes were detected, in $100 \%(27 / 27)$ and $85.2 \%(23 / 27)$ of the strains, respectively. However, unlike nanB, the occurrence of the $n a n H$ gene was variable when compared to the studies of Ewers et al. (2006) and Furian et al. (2016), who detected the nanH gene in $65 \%$ of strains in Germany and $95 \%$ of strains in Brazil, respectively. Regarding the genes encoding enzymes with antioxidant functions, $\operatorname{sod} A$ and sodC were present in $92 \%$ and $96 \%$ of the strains, respectively. These results are similar to those obtained by Furian et al. (2016), specifically to $P$. multocida strains of serogroup A.

Acquiring iron is important for survival and pathogenicity of $P$. multocida in the host (May et al., 2001). Among the genes involved in iron metabolism selected for the study, exBD-tonB and $h g b A$ were detected in $100 \%$ (27/27) of strains and $h g b B$ in $96.3 \%(26 / 27)$ of cases. Proteins that are part of the TonB complex are 
responsible for the energy required to internalize iron in the periplasmic space, regardless of the uptake mechanism (Krewulak and Vogel, 2008). The collection of genes involved in iron metabolism suggests that the bacterium has a redundancy of proteins involved the same function (Boyce et al., 2012). Examples are the $\mathrm{HgbA}$ and $\mathrm{HgbB}$ proteins, both of which are related to the uptake of iron from hemoglobin (Hatfaludi et al., 2010). Previous studies have shown similar results to those obtained by the analysis that showed the occurrence of the two genes (Ewers et al., 2006; Furian et al., 2016).

The gene toxA, encoding of dermonecrotic toxin, was not detected in any of the 27 strains analyzed. Although some studies detected it in strains from serogroup A derived different hosts, the gene is mainly associated with strains of serogroup D and in cases of progressive atrophic rhinitis in swine (Vougidou et al., 2015).

Usually, pathogenic bacteria have multiple adhesins that are correlated with virulence (Harper et al., 2006). The gene ptfA, which encodes a subunit of type IV fimbriae and has a high degree of similarity to other fimbriae (Hatfaludi et al., 2010), was detected in $100 \%$ of the strains. The type IV fimbria is a potential target for vaccines. The PtfA protein is anchored in $P$. multocida, independent of the serogroup, and it is expressed in vitro under microaerobic conditions comparable to the upper respiratory tract (Ewers et al., 2006; Shivachandra et al., 2012). However, $p f h A$ gene, which encodes a filamentous hemagglutinin, was detected in $81.5 \%(22 / 27)$ of the analyzed strains. This gene has a variable frequency and is possibly related to the more pathogenic strains of FC (Ewers et al., 2006; Tang et al., 2009).

\section{CONCLUSIONS}

FTA cards have proven to be a reliable tool for the transport of $P$. multocida DNA, since growth of $P$. multocida or other microorganisms was not observed. Similarly, the FTA cards demonstrated to be viable for use in the molecular analysis because the DNA was preserved, and the correct concentration of DNA required for gene detection by multiplex PCR was obtained. The majority of the virulence genes presented a high frequency and there was no significant difference in the occurrence of selected genes between strains isolated in the United States and Southern Brazil.

\section{REFERENCES}

AWAD, F.; BAYLIS, M.; JONES, R.C.; GANAPATHY, K. Evaluation of flinders technology associates cards for storage and molecular detection of avian metapneumoviruses. Avian Pathol., v.43, p.125129, 2014.

BOYCE, J.D.; ADLER, B. How does Pasteurella multocida respond to the host environment? Curr. Opin. Microbiol., v.9, p.117-122, 2006.

BOYCE, J.D.; SEEMANN, T.; ADLER, B.; HARPER, M. Pathogenomics of Pasteurella multocida. Curr. Top. Microbiol. Immunol., v.361, p.23-38, 2012.

BRASIL. Ministério da Saúde. Portaria n. 472 de 09 de março de 2009. Regulamento técnico Mercosul para transporte de substâncias infecciosas e amostras biológicas entre os estados partes do Mercosul. Diário Oficial da União, Brasília, 10 mar. 2009. Seção 1, p.31-32.

CHRISTENSEN, H.; BISGAARD, M. The genus Pasteurella. In: DWORKIN, M. (Ed.). The prokaryotes. New York: Springer, 2006. p.1062-1090.

CHUNG, J.Y.; ZHANG, Y.; ADLER, B. The capsule biosynthetic locus of Pasteurella multocida A:1. FEMS Microbiol. Lett., v.166, p.289-296, 1998.

CORTES, A.L.; MONTIEL, E.R.; GIMENO, I.M. Validation of Marek's disease diagnosis and monitoring of Marek's disease vaccines from samples collected in FTA cards. Avian Dis., v.53, p.510-516, 2009.

EWERS, C.; LUBKEBECKER, A.; BETHE, A. et al. Virulence genotype of Pasteurella multocida strains isolated from different hosts with various disease status. Vet. Microbiol., v.114, p.304-317, 2006.

FURIAN, T.Q.; BORGES, K.A.; LAVINIKI, V. et al. Virulence genes and antimicrobial resistance of Pasteurella multocida isolated from poultry and swine. Br. J. Microbiol., v.47, p.210-216, 2016.

GLISSON, J. Pasteurellosis and others respiratory bacterial infection. In: SAIF, Y. (Ed.). Diseases of poultry. Iowa: Blackwell Publishing, 2008. p.739-758.

GLISSON, J.; SANDHU, T.; HOFACRE, C. Pasteurellosis, avibacteriosis, gallibacteriosis, riemerellosis and pseudotuberculosis. In: DUFOURZAVALA, L. (Ed.). A laboratory manual for the isolation, identification and characterization of avian pathogens. Georgia: American Association of Avian Pathologists, 2008. p.12-18. 
GUIDANCE on regulations for the transport of infectious substances 2009-2010. (who/cds/epr/2008.10), 2009. Available in: <http://www.who.int/csr/resources/publications/biosaf ety/WHO_HSE_EPR_2008_10.pdf $>$. Accessed in: 12 Dez. 2016

HARPER, M.; BOYCE, J.D.; ADLER, B. Pasteurella multocida pathogenesis: 125 years after Pasteur. FEMS Microbiol. Lett., v.265, p.1-10, 2006.

HATFALUDI, T.; AL-HASANI, K.; BOYCE, J.D.; ADLER, B. Outer membrane proteins of Pasteurella multocida. Vet. Microbiol., v.144, p.1-17, 2010.

KATOCH, S.; VERMA, L.; SHARMA, M. et al. Experimental study of the pathogenicity of Pasteurella multocida capsular type B in rabbits. J. Comp. Pathol., v.153, p.160-166, 2015.

KREWULAK, K.D.; VOGEL, H.J. Structural biology of bacterial iron uptake. Biochim. Biophys. Acta, v.1778, p.1781-1804, 2008.

LIANG, X.; CHIGERWE, M.; HIETALA, S.K.; CROSSLEY, B.M. Evaluation of fast technology analysis (FTA) cards as an improved method for specimen collection and shipment targeting viruses associated with bovine respiratory disease complex. $J$. Virol. Methods, v.202, p.69-72, 2014.

MAY, B.J.; ZHANG, Q.; LI, L.L. et al. Complete genomic sequence of Pasteurella multocida, Pm70. Proc. Natl. Acad. Sci. USA., v.98, p.3460-3465, 2001.

MBOGORI, M.; KIMANI, M.; KURIA, A. et al. Optimization of FTA technology for large scale plant DNA isolation for use in marker assisted selection. Afr. J. Biotechnol., v.5, p.693-696, 2006.

MOSCOSO, H.; THAYER, S.G.; HOFACRE, C.L.; KLEVEN, S.H. Inactivation, storage, and PCR detection of mycoplasma on FTA filter paper. Avian Dis., v.48, p.841-850, 2004.

PEROZO, F.; VILLEGAS, P.; ESTEVEZ, C. et al. Use of FTA filter paper for the molecular detection of newcastle disease virus. Avian Pathol., v.35, p.93-98, 2006.

PULIDO-LANDÍNEZ, M.; LAVINIKI, V.; INGUNZA, R.S. et al. Uso dos cartões FTA para o transporte de amostras de DNA de Salmonella spp. isoladas de produtos avícolas do sul do Brasil. Acta Sci. Vet., v.40, p.1-7, 2012.
PULIDO-LANDÍNEZ, M.; SÁNCHEZ-INGUNZA, R.; GUARD, J.; NASCIMENTO, V.P. Assignment of serotype to Salmonella enterica isolates obtained from poultry and their environment in southern Brazil. Lett. Appl. Microbiol., v.57, p.288-294, 2013.

SHIVACHANDRA, S.B.; YOGISHARADHYA, R.; AHUJA, A.; BHANUPRAKASH, V. Expression and purification of recombinant type IV fimbrial subunit protein of Pasteurella multocida serogroup B:2 in Escherichia coli. Res. Vet. Sci., v.93, p.1128-1131, 2012.

SUBAAHARAN, S.; BLACKALL, L.L.; BLACKALL, P.J. Development of a multi-locus sequence typing scheme for avian isolates of Pasteurella multocida. Vet. Microbiol., v.141, p.354361, 2010.

TANG, X.; ZHAO, Z.; HU, J. et al. Isolation, antimicrobial resistance, and virulence genes of Pasteurella multocida strains from swine in China. $J$. Clin. Microbiol., v.47, p.951-958, 2009.

TOWNSEND, K.M.; FROST, A.J.; LEE, C.W. et al. Development of PCR assays for species- and typespecific identification of Pasteurella multocida isolates. J. Clin. Microbiol., v.36, p.1096-1100, 1998.

TSAI, Y.C.; SHIEN, J.H.; WU, J.R. et al. Polymerase chain reaction-restriction fragment length polymorphism analysis of the genes involved in the biosynthesis of the lipopolysaccharide of Pasteurella multocida. J. Vet. Diagn. Invest., v.23, p.543-546, 2011.

VOUGIDOU, C.; SANDALAKIS, V.; PSAROULAKI, A. et al. Distribution of the ompAtypes among ruminant and swine pneumonic strains of Pasteurella multocida exhibiting various cap-locus and toxA patterns. Microbiol. Res., v.174, p.1-8, 2015.

WILKIE, I.W.; HARPER, M.; BOYCE, J.D.; ADLER, B. Pasteurella multocida: diseases and pathogenesis. Curr. Top. Microbiol., v.361, p.1-22, 2012.

WILSON, B.A.; HO, M. Pasteurella multocida: from zoonosis to cellular microbiology. Clin. Microbiol. Rev., v.26, p.631-655, 2013. 